\title{
New Disease Reports \\ First report of a variant of Tomato leaf curl Bangladesh virus infecting Gaillardia
}

\author{
L. Mahatma ${ }^{1} *$ and M.K. Mahatma ${ }^{2}$ \\ ${ }^{1}$ Department of Plant Pathology, N.M. College of Agriculture, Navsari Agricultural University, Navsari 396 450, Gujarat, \\ India; ${ }^{2}$ Department of Plant Molecular Biology and Biotechnology, ASPEE College of Horticulture \& Forestry, Navsari \\ Agricultural University, Navsari 396 450, Gujarat, India
}

*E-mail: mahatmalalit@yahoo.co.in

Received: 06 May 2012. Published: 09 Aug 2012. Keywords: whitefly, geminivirus

In October 2009 leaf yellowing symptoms of Gaillardia, popularly known as blanket flower (Gaillardia pulchella) were observed in more than $50 \%$ of plants growing in fields of Fatehnagar village in the Udaipur district of Rajasthan, India. Infected plants exhibited vein yellowing (Fig. 1) where in severe extreme cases entire leaflets showed severe yellowing, crumpling and distortion (Fig. 2). Infected plants were dwarfed with smaller sized flowers and had reduced or no commercial value. A similar incidence of diseased plants with identical symptoms was noted in the fields in 2010 and 2011 together with the appearance of diseased plants in a nearby lawn. It was shown that the causal agent of the disease was transmitted by whiteflies (Bemisia tabaci) by artificial inoculation of susceptible plants following a six hour acquisition and inoculation feeding period by whiteflies; this produced similar symptoms to those observed in the field

The presence of a Begomovirus was detected by PCR using Begomovirus specific oligonucleotide (Rojas et al., 1993). A full-length DNA-A molecule $2761 \mathrm{bp}$ long was amplified from symptom-bearing leaves and itssequence submitted to GenBank (Accession No. JQ765395). Sequence analysis using the BLAST programme revealed nucleotide sequence identities of $94.0 \%$ with Tomato leaf curl Bangladesh virus-[Bangladesh:2] (ToLCBDV-[BD:2]) (AF188481), and 92.0\% with Chilli leaf curl virus-DU [India: New Delhi:Papaya:2009 (HM140364). As per the criteria proposed by Fauquet et al. (2008) the virus infecting Gaillardia is considered to be the variant of Tomato leaf curl Bangladesh virus-[Bangladesh:2]. Accordingly the virus was named as Tomato leaf curl Bangladesh virus-Gaillardia [India:Udaipur:Gaillardia:2009]

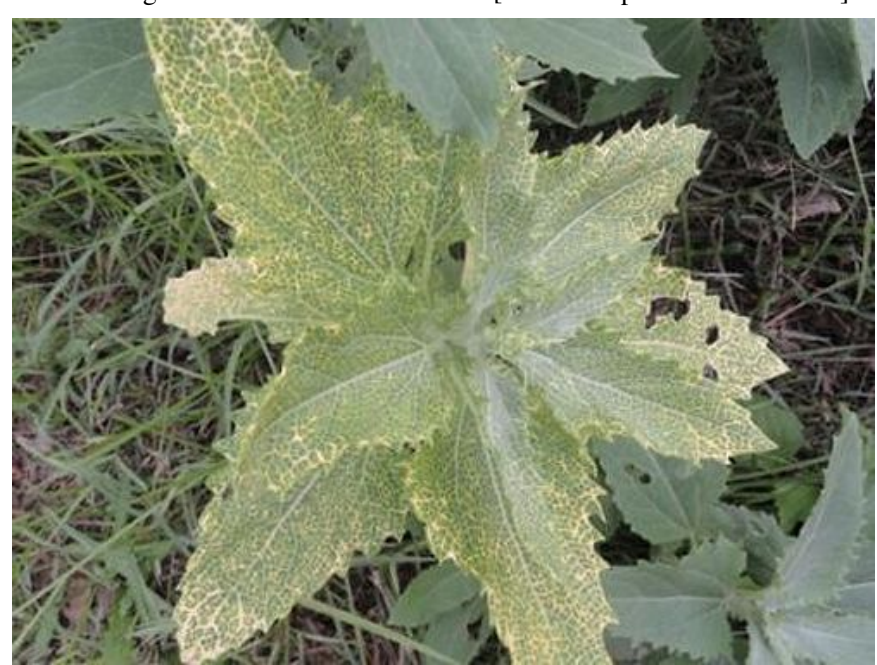

Figure 1
ToLCBDV-Gaill [IN: UDR: Gaill: 2009].

This is the first report of Begomovirus infection of Gaillardia. Begomoviruses are causing devastating losses to economically important vegetables, pulses, ornamentals and fibre crops. In pulses alone such viruses have been estimated to cause USD 300 million losses (Varma \& Malathi, 2003). Commercial floriculture in India is a rapidly expanding industry and disease impact is an important factor. Gaillardia is one of the hardiest annuals grown on a variety of soils. It is an attractive flower available in single or semi-doubles with appealing colours. It is an important substitute to the well-known cut flower chrysanthemum.

\section{References}

Fauquet CM, Briddon RW, Brown JK, Moriones E, Stanley J, Zerbini M, Zhou X, 2008. Geminivirus strain demarcation and nomenclature.

Archives of Virology 153, 783-821.

[http://dx.doi.org/10.1007/s00705-008-0037-6]

Rojas MR, Gilbertson RL, Russell DR, Maxwell DP, 1993. Use of degenerate primers in the polymerase chain reaction to detect whitefly transmitted geminiviruses. Plant Disease 77, 340-347.

[http://dx.doi.org/10.1094/PD-77-0340]

Varma A, Malathi VG, 2003. Emerging geminivirus problems: A serious threat to crop production. Annals of Applied Biology142, 145-164. [http://dx.doi.org/10.1111/j.1744-7348.2003.tb00240.x]

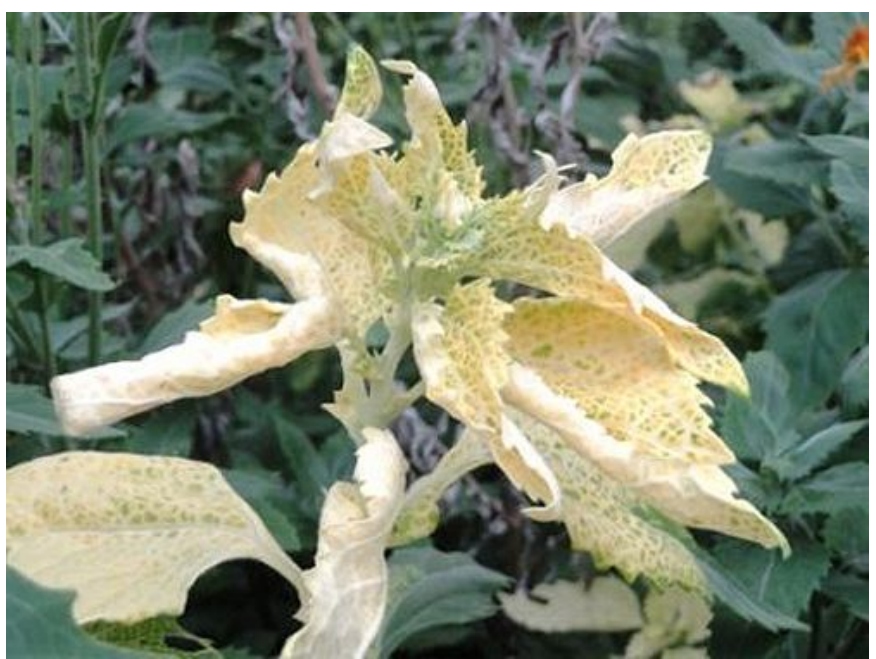

Figure 2

To cite this report: Mahatma L, Mahatma MK, 2012. First report of a variant of Tomato leaf curl Bangladesh virus infecting Gaillardia. New Disease Reports 26, 4. [http://dx.doi.org/10.5197/j.2044-0588.2012.026.004]

(C) 2012 The Authors

This report was published on-line at www.ndrs.org.uk where high quality versions of the figures can be found. 